\title{
OZO TITLE INSTITUTION IN IGBO LAND IN RELATION TO POLITICS IN NIGERIA: A COMPARATIVE ANALYSIS
}

\author{
Innocent Ogbonna Nweke* \\ http://dx.doi.org/10.4314/og.v15i1.6s
}

\begin{abstract}
Politics, they said is a dirty game. One tends to disagree with this assertion because man is a political being and everything man does is all about politics. It depends on the intention, and how each plays his or her own. Ozo title is one of the political institutions in Igbo land. It will be worthy to mention that the Ozo title meant in this paper is the primordial or original Ozo title in Igbo land and not the adulterated Ozo title today. It is one of the institutions that helps in governance, controls different sectors of the Igbo man's life and equally checkmates the excesses in the land. This work tries to look at the politics in the Nigerian setting and that of the Igbo land as being championed by Ozo title men. It x-rays their day-to-day activities and compares them. The work equally will be able to evaluate the two. During the evaluation, it was discovered that politics is not dirty, it was also discovered that since the Ozo title men play this politics and play it very well, it now boils down on the makeup of the individual and the intentions of the people in it. It however suggests that the Nigerian leaders or politicians should look at the Ozo title institution and what it is for the Igbo man and borrow a leaf from them. The paper uses socio-cultural approach in the work. The paper finally warns that the Ozo title as used in this study is the primodial one and not the adulterated one. Thus, if the politicians in Nigerian today borrow from the Ozo title men in Igbo land, politics in Nigeria will be a better and an interesting one.
\end{abstract}

Key words: Ozo title, Igbo land, Leadership, Politics, Nigeria.

\section{Introduction}

Man is a political being or political animal, what it implies is that man cannot do without politics. His day to day activities has elements of politics in them. However, some people have termed this politics dirty. Why terming it dirty? Perhaps, it is because of the way it is being played today. But the question still remains, is politics 
Nweke: Ozo Title Institution in Igbo Land in Relation to Politics in Nigeria...

dirty or the people involved are dirty? Definitely, the answer would be that some politicians are dirty, and not that politics itself is dirty.

Consequently, African culture especially Igbo land has its leadership before the advent of our colonial masters. She has its own ways of making laws and checkmating the offenders and bringing them to book. One of the political institutions which Igbo man has, is the Ozo Title Institution. The institution is well respected in Igbo Land and they are in-charge of making laws and executing of laws also through the help of the age grade and masquerade culture, the Ozo Institution is a political institution that does not allow any dick and harry as member, there is an objective way of selecting the members, thus many have to follow due process which will be concluded with consulting the oracles or deities. The Ozo title institution we are dealing with is the primordial one and not the adulterated one of today's Igbo land. This institution does not collect bribe in the discharge of their duties, they have the fear of the gods and so once you fulfil all the required rituals after the screening exercise, you become literally onye Ozo (one Ozo) "another person". One is now transformed both in character and otherwise, the watchword of the members becomes objective truth, justice, equity and fairness. They reject corruption, injustice, hence having being selected objectively both by the pods and the people, the person is what he does.

Subsequently, the experience of the Ozo title institution in Igbo land and the Nigeria politics of today have sharp differences. The Nigerian politics of today is devoid of objectivity in selection of the leaders. It is equally devoid of corruption. One of the objectivity in the selection of leaders are missing, it carries injustice and other things along with it. The aim of this paper is to critically x-rays the style of politics in Ozo Title Institutions and the politics in Nigeria today. The researcher will try to evaluate the politics of Nigeria today and that of Ozo title Institution in Igbo land and make a recommendation on the best style that will benefit the Nigeria society for better productivity.

\section{Clarification of Concepts \\ Ozo Title}

Ozo Title is the highest and most important spiritual, religious and social grouping in the Igbo Society of Southern Nigeria. To become Ozo person implies that the title holder is now an 'Nze' or onye 
'nze' which implies living spirit and an ancestor. Augustine Obi in his words when interviewed, sees 'Onye Oze' literally as an Ozo person. For him, after taking the title, the person becomes "Onye Ozo" which he translated literally as 'Onye Ozo' which implies another person. He explains that the person becomes another person rather than what he was formerly.

\section{Igbo Land (People) and their Origin}

There are so many versions of Igbo origin and it is very difficult, or probably impossible to say which is the most real or most acceptable. Unlike the Yoruba who trace their origin to Oduduwa in Ile-Ife and the Hausa who trace their origin to Bayafidda in Daura, the Igbo people have no such historical identification with a founding father or founding home.

According to Okoli (2018) in his article on Ozo Title in Igbo Land asserts that, the most popular version so far is that the Igbo are descendants of Jacob who later became known as Israel. He had 12 sons, and the $7^{\text {th }}$ son of which was known as Gad (Gen. 46:15-18). Famine caused Jacob and his sons to migrate to Egypt where there was an abundance of food at the time they remained in Egypt for many years and prospered causing the Egyptians to became envious and began to persecute them.

Gad had seven sons and Eri was the $5^{\text {th }}$ of them. Before the Egyptian persecution began, Eri in company of his family and associates left Egypt after catching an inkling of impending persecution against his people. They travelled several miles and hills to cross the River Nile and entered Southern Sudan, and moved onto Chad. From Chad, they crossed River Benue and Came to Lokoja. From Lokaja, they sailed through River Niger and came ashore around $1305 \mathrm{BC}$ at a place known as Agbanabo, located near present day Aguleri, where, according to oral tradition, it was spiritually or divinely - day Aguleri, where, according to oral tradition, it was spiritually or divinely revealed to Eri that Agbanabo (the confluence point of Ezu and Omambala Rivers) was to be their final destination and settlement. Eri built a structure where he regularly offered prayers and spiritual rites to God and to honour his own father Gad. But they did not stay there for long, because of the constituent flooding of the two rivers. They moved into the Hinter land and settled in the present - Aguleri. Meanwhile, Eri had his own children 
Nweke: Ozo Title Institution in Igbo Land in Relation to Politics in Nigeria...

of which Agulu was the elders, who look over from his father Eri, who lived and died at Aguleri centuries ago. Thus, Eri became the patriarch of all Igbos.

\section{What is Leadership?}

According to James Igbabee (2018), Leadership is a concept which is often talked about and which has generated a proliferation of literature. (P. 92). Leadership can be understood in the sense of reserving the right and privilege to show direction, and influencing others into doing things. It involves an activity vested in the tradition and culture of humanly made manifest in a person who transmits its functionality to traditional, organizational and transformational process of performing a duty, and of being responsible for controlling, managing and accounting for lives, properties, issues, beliefs and practice.

According to Gowon (2009) in James Igbabee (2018), leadership encompasses the totality of the human capacity that is displayed or can be put into driving a process at various levels in society for purpose of providing necessary commonly guidance to the follow ship (P. 93). This according to Gowon can be understood in getting others to follow, that is the ability to inspire confidence and support among the people who are needed to achieve organizational goals and may be exercised as an attribute of position, or because of personal knowledge and wisdom.

\section{Ozo Title in Igbo Land and their Style of Leadership}

According to oral traditions from various parts of Igbo Land, the origin of the Ozo Institution can be traced back to the first Eze Nri Ifikuarim, who established the Ozo Title during Nri ascending from $9^{\text {th }}$ century, increasing through the $12^{\text {th }}$ to $15^{\text {th }}$ centuries and declining until collapse on the British ban of Nri activities in 1911.

The Ozo Title is a status symbol in Igbo Land, taken by those who can afford it or who have relations or friends to sponsor them provided they are people of upright character and integrity and are respected throughout the community. It is usually for mature males who are reasonably sound and well established materially.

According to John Nweke (2019) who is an Ozo man, when interviewed, he opined that Ozo Title is a respected institution in Igbo Land, he emphasized that it is for upright people, and he 
concludes that one of their rules in Igboland is to present an exemplary leadership for the young to emulate.

There are two studies that traced the origins of Ozo Title in Igbo Land. One is from the sociologists and anthropologists who believe that Ozo Title Institution grew as a form of social security or old age pension in traditional pleasant Igbo society, wherein mature men only could invest their agricultural wealth in the form of crops and livestock into the taking of the title from which they derived much dividend from the new entrants. In this way, they secured for themselves the means of livelihood in old age, a kind of pension, when they can no longer work.

Another convincing study is that, they Ozo Institution grew out of the need of priests and upright men who would preside at extended family and lineage worship and supervise the cult of the ancestors and keep the family ofo stick, which is a symbol of truth, justice and fairness. The study believed that the continuity of the lineage, clan or community depends on the existence of God fearing men who share in the spirit of the land through their special relationship with the earth goddess (Ala), and also who know how to placate the spirit of the dead ancestors and uphold the ordinances of the land.

Commonly, these two studies made important contributions to our study especially on the qualities of the would-be Ozo Title men which includes, uprightness, honestly upholding justice, presiding at events of the clan, and mediating between the living and dead. However, Ozo Institution is respected in Igbo land not because of their wealth, but because of the honesty, uprightness and justice which they exhibit in their leadership style, especially when presiding over cases and when managing the finance and common good of the people in their clan or village.

\section{The Stages of Ozo Title Taking}

It must be noted however, that Igbo believe in customizing and personalizing culture. That will explain the variations you find in the way several communities handle the Ozo Title taking in their community.

The Notice of Intent and Announcement: Upon securing the support of the kinsmen, the candidate consults with the Ozo 
Nweke: Ozo Title Institution in Igbo Land in Relation to Politics in Nigeria...

fraternity through their leaders to obtain the requirements. This visit is usually made with 8 (eight) Igbo kola nuts, a bottle of gin and monetary gifts as prescribed by the fraternity. He may be accompanied by friends and immediately, words will quickly go round about his intention.

Ibu ego Ozo and fulfillment of rites: On the appointment day agreed with the fraternity, the aspirant invites the Ozos to his house where he will present all the requirements of cash, yams, cows, goats, cockerels and other mandatory gifts to the Ozo Title holders as prescribed by the fraternity. Members of the fraternity are lavishly entertained at this stage.

The title conferment ceremony: This is the day to which all and sundry are welcomed to come and eat, drink and be entertained several cows, goats and cockerels are butchered. Food and drinks are served in abundance. The installation will now take place after the entertainment, and it is performed by the chairman of the Ozo fraternity in the presence of all other Ozo members. The candidate is given the regalia of Ozo title men and a name which he has chosen.

The Ozo dance: This is the completion of the installation ceremony. The new Ozo man dances the 'Ufie' dance and accompanied by his wife and other Ozo title holders.

The fattening/recovery period: This is the incubation period for the new Ozo to recover physically and mentally from the stress of the ceremony. He stays indoors for 8 market days, during which he is well fed and nourished in preparation for market outing (Izu afia Ozo). He is spared with any case or cases of the community in these eight days.

The market outing (Izu afia Ozo): The new Ozo is escorted to the market square by noon on the appointed market day dressed in his Ozo regalia. He is accompanied by his richly decorated and well adorned wife or wives, alongside his kinsmen and merry makers. $\mathrm{He}$ proudly parades himself and his escorts around the entire market for all to see and acknowledges that he is now a titled man. People are given the opportunity to see him and pay him homage. 


\section{The Un-making of an Ozo}

It is worthy to mention that an Ozo man can be relinquished of his Ozoship if he commits any abominable acts (nso ani) or abomination (alu) or convicted of stealing. This is regarded as desecration of the Ozo title. The Ozo concerned must undergo full cleansing, make atonements, reparation and remediation before he can be re-admitted into the fraternity

\section{Politics in Nigeria Today}

Nigeria as a nation has its political system which is not functional. It is not functional due to many factors namely selfishness, disinterestedness in one Nigeria, pluralistic nature of Nigeria, corruption etc. These factors are further explained as follows:

\section{Selfishness}

The Nigerian populace are generally interested in themselves other than the common interest. Most people are interested in power, in governance, just to rule and not to serve. Leadership is all about service but in Nigeria it is not the case, many go into Houses of Assembly, Senate, House of Representative and other political post in Nigeria only to lord it over to others, make laws for the masses that they can never keep themselves. The politicians do not understand what it means to lead that; to lead is to serve. Nweke (2018) in Clark (1995) in his view about politics in Nigeria asserts that: "Corruption, though a universal phenomenon, appears to have become so endemic in Nigerian politics that most discoveries about the country here and elsewhere, centre more on the high ascending of corruption in our public life" (pg 169). For him, the political system in Nigeria is characterized by corruption which is as a result of selfishness that made people to think of themselves, their pocket at the expense of others they are governing.

Consequently, in this politics of selfishness, a lot of people who are supposed to talk are not talking, some are afraid and some have no interest. Ogbunweze (2004) has it that the only thing it takes for evil to triumph and be crowned or canonized a norm, is for good men to grovel in silence and in action. (p.4). What this means is that silence is tantamount to a collaborative conspiracy with the evil that is on the wings of asserting himself over night and justice. 


\section{Disinterestedness in One Nigeria}

Most people in Nigeria are not interested in One Nigeria. There are different groups and sets who are agitating for segregation because of inequitable sharing of the national case. We have in the east, indigenous people of Biafra (IPOB), in the west, we have Arewa Peoples Congress, in the North we have Northern Peoples Assembly and in the Niger Delta we have the Niger Delta consultative forum. Thus Abubakar (2018) asserts (the major problem facing the nation an entity is that of unity the different segment of the community as one lack of the understanding is the cause of some of the nation's problem, for example, lack of patriotism among many Nigerians and the problem of sectarianism among some ethnic groups P. 146).

He implies that Nigeria lack the will of national identity as a people, these can be seen in the evidences we have about excessive corruption and bribery. The severe ethnic attainment are indicators to lack of patriotism among citizens - solving these problems require changing human perception in the country.

\section{Pluralistic nature of Nigerian}

The pluralistic nature of Nigeria as it concerns religion is affecting the politics negatively. In Nigeria we have three major religion Christianity, Islam and African Traditional religion. Each of this religion is struggling for supremacy and indirectly distracts the affairs of the administration. There is need for the three major religious to come together in understanding to help those in the administration.

Abubakar (2018) asserts that Nigeria as a nation needs the support of all Nigerians both Muslims, Christians and followers of other religions as well as different ethnic groups, as citizens of the country. The unavoidable mixture in which different religious find themselves can be utilized as secret for the country development ( $\mathrm{p}$. 146). According to Abubakar, the make-up of the religions is supposed to be a force to encourage, assist government in achieving its good purpose for the people they are governing, but the different religions instead of becoming a blessing to the Nigerian politics, turned out to be a curse.

\section{Corruption}


Corruption has become a cankerworm that has eaten deep into Nigerian nation. It has also become a household word that every administration that comes in will have it as one of the agenda to curb. It has gone into different levels of human life in Nigeria. Nweke (2018) opined that corruption in politics is institutionalized such that not only that officials are corrupt, but that corruption is the officials themselves. This political corruption has affected Africa in different areas like, waste of resources, reduction of government administrative capacity and loss of legitimacy, creating undesired feeling of frustration and disgust. (p. 168). The corruption according to Nweke has eaten deep into the life of every person in Nigeria.

Abubakar supported this by saying that, Christianity and Muslim cooperate in federal and state governments and in private and public work place. Both Muslim and Christians serve as government officials, president, vice president, ministers, senators, governors, commissioners and other important positions in the country. They do it very well without having problem among themselves. (p. 148). Abubakar proffered solution to this corruption in Nigerian and according to him, the leaders of the religions we have in the country should come together, since they can stay together in government without problem, they can equally use their positions to advice the leaders on how to share the resources and handle the people put in their care.

\section{Comparative Analysis of the Two Stages of Leadership: Ozo title Style of Leadership and the Nigerian Political System}

Having $x$-rayed the Ozo title institution in Igbo Land, their requirements and the stages, and also the political system of Nigeria and their short comings, it would be necessary to compare the two to know which one will be preferable and should be proposed for Nigeria as a nation as follows:

Respected institutions: Ozo title institution is a respected institution in Igbo Land. The members are respected and they are respected because they maintained what Ozo title stands for in Igbo Land. A question should be asked whether the politicians of Nigeria are respected, the answer is No! Instead people are afraid of them, less you be maimed or lose your life. The Ozo title institution have rules which are followed and people are confronted, corrected and if possible sanctioned. However, in the Nigeria political system, you 
Nweke: Ozo Title Institution in Igbo Land in Relation to Politics in Nigeria...

dare not talk of the rules correcting or sanctioning politicians. All the rules are on paper and not followed.

Uprightness/honesty: From what we learnt about Ozo title institution, they are given a (staff) that is (ofo) which symbolizes justice and uprightness. This presupposes that the individual will be honest and should uphold justice when handling any case of sharing the common good that belongs to all in the clan. However, the politicians of country are known for lies, they build and construct roads on television. They say what they cannot do for the people, promise people heaven and earth and at the end, they will not do even one of them.

Exemplary life: The Ozo title men are known for their exemplary life, bearing in mind that they are respecting their clan. They have the interest of that clan people at heart, and that of the institution. Hence, they carry themselves with dignity where ever they go and whatever they do. In the Nigerian political system, the representatives of the people in different parastatals like Houses of Assembly, Representative, Senate, do not think of the people they represent. Their interest is in themselves and that is why they can afford to fight for money instead of the people they are being represented.

The continuity of the lineage: The Ozo title men knows that the continuity of his lineage, clan or village depends on them. By remembering this, they will be careful, less they go into extinction. With regard to the political system of Nigeria, the leaders are not interested in the people they are representing and their continuity. Their interest is more important than that of the people. Whether the people are dying or suffering is not their business instead their lives, family lives and pockets are what they struggle for.

Mediating between the living and the death: African man is notoriously religious. The worldview of the African is connected in such a way that the world of human and that of the ancestors are united, such that you do not do anything as an African man without taking cognizance of the ancestral world. The Ozo title men mediate between these two worlds and so will always be very careful in their 
Ogirisi: a new journal of African studies vol. 15s 2019

dealing with the world they are living in; they should remember that the ancestors, the gods are alive and watching. This is against what practice of the leaders or politicians in Nigeria. They do not fear or remember that God exists, they do not remember that the oath they took when entering into office, their interest is only on today's life and not life after God.

Objective screening and seriousness with the oath of office: In the traditional Igbo land, you do not just become an Ozo titled man. You must pass through strenuous screening that is devoid of ringing or malpractice. The rules for screening are followed strictly. The procedures in the different stages are also followed without anyone jumping hurdle or protocols; objectivity is their watchword. Thus, in Nigeria political system, there is nothing like credible or free and fair screening or elections, many come in through rigging, and when you come in through rigging, what did you expect the person to do? Definitely, the person will avoid the rules because the person did not come in through due process. The person in question will also go to any length to protect the foul means that brought him into the office.

\section{Recommendations}

- The leaders of Nigeria should focus more on the style of leadership of Ozo title people.

- The politicians of Nigerian should look at Ozo title men, their makeup and their exemplary life.

- The Nigerian leaders should ask themselves what they are to the people they are representing, in relation to honesty.

- Politics should not be seen as a dirty game, instead people should embrace it in all honesty and sincerity.

- The style of screening for the Ozo title in Igbo Land should be adopted by the Nigerian political system with every strictness and objectivity.

- Let there also be un-making of Nigerian politicians just as we have in Ozo title institutions, especially with regard to sanctioning anyone who commits crime. This should be strictly adhered to.

\section{Conclusion}


Nweke: Ozo Title Institution in Igbo Land in Relation to Politics in Nigeria...

Having gone through what Nigerian political system have suffered, the Ozo title institution and their style of leadership, the comparison has also shown the two styles of leadership of the Nigerian system and Ozo title institution. However, the aim of this work is to propose a better political system that Nigeria will adopt since, she has tried a lot of systems of governance and it has failed her.

Thus, this study has also shown that the Ozo title institutional political system is more practicable and better, if adopted by the entire Nigerian populace especially the leaders. The leaders should focus more on the style of screening of candidates, taking oath for what it stands for, being honest and upright, and bearing in mind that the things we do here on earth, do not end in this world but hereafter.

*Innocent Ogbonna Nweke Cssp, PhD, Department of Religion and Society, Chukwu Odumegwu Ojukwu University, Igbariam Campus. Anambra State.ekedion@yahoo.com. 


\section{References}

Abubakar, D. (2018). Muslim - Christian Relations in Nigeria. The need for co-existence. Journal of Religious and culture. Vol 18. No. I. 2018 Uniport publication. P. 146.

Igbabee, J. (2018). Leadership and Challenges of Development in Nigeria. Journal for the study of Religious. Vol. 28. No.1. 2018. Decency Printers and Stationeries Ltd. Ilorin Nigeria Pg 92.

Nweke, I.O. (2018). African Traditional Religion in the midst of speculation. Onitsha: Spiritan press.

Ogbumezeh, J. (2004). The price of silence in Nigeria: unpublished article St. Joseph Major Seminary Ikot Ekpene.

Okoli, J. (2018). The Ozo fraternity in Igbo Land: Akpueze case study. http://www/academio.edu.

Punemberg, W. (1969). Christianity in a secularized world. New York: Crossroad.

Ugwu, C.O. (1999). Man and his religion in a contemporary society, Nsukka: MCK social press.

Uzoukwu, E.E. (1996). A listening church: Autonomy and communication in African churches. Emmau: SNAPP press. http://www/academa-edu

\section{Oral Interview}

Nweke John $17^{\text {th }}$ October, (2019) 96years Awkuzu, Oyi L.G.A.

Obi Augustine $17^{\text {th }}$ October, (2019) 75 years Awkuzu, Oyi L.G.A.

Umeadi Nwankwu $17^{\text {th }}$ October 2019 Nteje

Nwagbo John $12^{\text {th }}$ October 2019 Nneun

Nwaregbo Patrick $9^{\text {th }}$ October, 2019 Umuoba, Anam

Mgbofor Okolo 17 ${ }^{\text {th }}$ October, 2019 Igbu, Awkuzu

Okeke Elizabeth $17^{\text {th }}$ October, 2019 Umuoli, Awkuzu 